\title{
Historical Discord: The Question of Greek Women
}

\author{
Caitlyn Coil ${ }^{1 *}$
}

\begin{abstract}
Ancient Greek women and their roles have long been a topic of debate among historians. Classical study from previous generations found that Greek women were wholly deficient of all power and rights within the state. Historian A.W. Gomme argued that Greek women spent their lives trapped within their husband's homes. Textbook writers such as Maurice Balme and Gilbert Lawall replicate Gomme's viewpoints. In the text Athenaze: An Introduction to Ancient Greek, Balme and Lawall discuss the roles of ancient Greek women for only two pages and pronounce that women "lived in the shadows of their men" and lacked all legal abilities since "they were treated in law as minors."'Balme and Lawall also parrot Gomme's view that women "had no place in public life." Contemporary historians, however, have found primary sources and literature which illustrate the true societal roles and powers of Greek women. Those accounts conflict heavily with the findings of scholars from the early twentieth century, such as Gomme, and those who replicate his bias. This dissension between historians on the social, economic, and political rights of Greek women is due in part to scholars' bias-laden interpretations of evidence. The primary sources about and written by Greek women must be presented and read with new interpretation to avoid the bias of previous historians. This paper seeks to rectify the inaccuracies in previous historians' analyses of Greek women by investigating the social, political, and economic power held by various women within the Greek world, as demonstrated in art, religion, and literature.
\end{abstract}

\section{Keywords}

Greek Women - Sparta - Greek Athletics

${ }^{1}$ Department of History, University of North Texas

*Faculty Mentor: Dr. Christopher J. Fuhrmann

\section{Contents}

\section{Introduction}

1 The Conventional Historiographical Perspective

1.1 Feminine Art . . . . . . . . . . . .

1.2 Female Deities and Religious Significance . . . . 3

1.3 Athenian Women ............... 3

2 Ancient Literature about Greek Women 4

2.1 Lysistrata . . . . . . . . . . . . . . . . . . 4

3 Women in Greek Philosophy and Literature

6

4 Legal Rights of Greek Women

5 Ancient Literature written by Greek Women

6 Conclusion: Historical Discord

Author Biography

\section{Introduction}

While it is debated how much power Spartan women held in the archaic period, it is universally agreed that they had higher social and legal standing than their counterparts in the rest of classical Greece. ${ }^{1}$ Spartan women held true power

\footnotetext{
${ }^{1}$ Paul Cartledge, The Spartans: An Epic History, (London: Channel Four, 2002), 153; A. W. Gomme, "The Position of Women in Athens in the Fifth
}

in their homeland because the city of Sparta was founded on the idea that bearing and raising children to be soldiers was vital to a militarized society. The militarization of their society also led to female empowerment simply because men were often absent in war. ${ }^{2}$ Although only men fought in battle, the Spartan people still demanded that all women stay at peak physical condition. Women held as much respect as men did in Spartan sports. ${ }^{3}$ Young girls were expected to continue state schooling until an older age than boys and to participate regularly in sports including nude wrestling, track, and hurdles. ${ }^{4}$

The activities of Spartan women outside of the domestic sphere did not end when they reached adulthood. An epigram was found written in $249 \mathrm{BC}$ in honor of Berenice II, a Macedonian professional charioteer whose teams competed in the Olympic Games. ${ }^{5}$ Berenice's epigram was most likely written as a type of autobiography. She states that she "won all three chariot races in one contest" and that her "holy family of women" saw these victories as the "prize-winning children

\footnotetext{
and Fourth Centuries," Classical Philology 20.1 (1925): 1.

${ }^{2}$ Cartledge, The Spartans: An Epic History, 154.

${ }^{3}$ P. Christesen, "Athletics and Social Order in Sparta in the Classical Period," Classical Antiquity 31.2 (2012), 193.

${ }^{4}$ Cartledge, The Spartans: An Epic History, 155.

${ }^{5}$ All translations are from Diotima unless otherwise noted.
} 
of children."6 Berenice was literate enough to write epigrams about her wins along with other wins of her female family members. She also traces her heritage through the women of her family. Greek men also wrote of Berenice and named her the Zeus of Nemea. Many more illustrative epigrams listing the achievements of ancient Greek women can be found within the archives of Diotima: Materials for the Study for Women and Gender in the Ancient World.

There is also evidence that young women competed with one another in areas outside of athletics. A Spartan man named Alkman wrote the Hymn to Artemis for a team of young girls to sing in a choir. ${ }^{7}$ These all-girl choirs would compete with one another to build the skills of young women beyond the field of athletics. It was believed that strong and intelligent women would birth capable future citizens for Sparta, male or female. A female child was not looked down upon, and Sparta had little female infanticide, unless the child was physically handicapped. More often than not, women in Sparta were left to run things while men fought in war. Since the men were away, women needed to have the legal ability to control the state and households in the men's stead. Spartan women could own and manage property. Inheritance also passed down via women, just as much as through men. Women who held total inheritance were referred to as "patrouchoi." 8 Athenian women were granted a similar type of inheritance right referred to as "epiklêros." " Women were referred to as epikleros when the men within their father's family line had died and they needed to keep ownership of property. These women were usually forced to marry their nearest relative on their father's side but in many cases they retained the property and wealth themselves. Although Sparta was exceptional, the situation there shows that ancient Greece was capable of producing a clearly positive social standing for women.

\section{The Conventional Historiographical Perspective}

Historians of the early twentieth century claimed that the women of Athens were bound politically, socially, economically, and sometimes physically to the homes and bedrooms of their husbands. The classical historian Gomme argued that women of higher classes had no power in the eyes of the law and were rarely allowed to leave the rooms in which their husbands had locked them. ${ }^{10}$ Athenian women were expected to live secluded lives so they would not be seen by men other than their husbands. They were treated with contempt and the best thing that could be said about a women was that she is "least talked of amongst men either for good or for evil."11 Athenian men supposedly believed a woman's place was to be invisible in the home. Gomme and other historians of his time

\footnotetext{
${ }^{6}$ Berenice II, Translated by Mary R. Lefkowitz

${ }^{7}$ Alkman Parthenion

${ }^{8}$ Cartledge, The Spartans: An Epic History, 156.

${ }^{9}$ Michael Grant, The Rise of the Greeks (New York: Scribner, 1988), 31.

${ }^{10}$ Gomme, "The Position of Women in Athens", 1.

${ }^{11}$ Thucydides 2.45 .
}

projected Thucydides' beliefs about women onto all of Greek culture. However, a considerable amount of the literature on Greek women clashes with these ideas. The idea that women were meant to be invisible before man does not coincide with the regularity of artistic depictions of women as beautiful and important within both art and literature.

\subsection{Feminine Art}

Greek women were often featured in artistic renditions of heroics and important ancient rituals. The powerful Amazonians were frequently portrayed in scenes of fighting, such as the one pictured below. Mortal Greek women were most often illustrated taking part in important rituals in which they commonly held leadership roles as seen in Figure 2, in which women lead a chariot. Depictions of women on rings were often worn by Greek men, while funeral statues of women were most frequently created by their husbands or by male family members, as seen below. The last artwork pictured exhibits a scene of intimacy between three women existing in a sphere without men. The women could even represent attentive students of the poet Sappho.

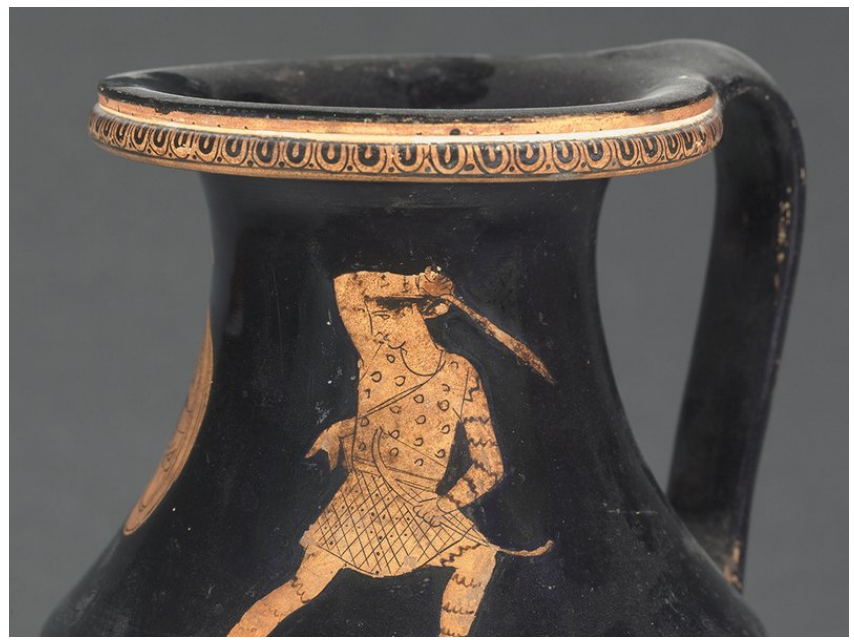

Figure 1. Greek, Classical, RMN-Grand Palais

The above picture of a painted vase depicts a mythical Amazonian woman who the Greeks believed ruled the more barbaric portions of the world. These women were respected warriors of legendary status.

This black painted terracotta jar (Figure 2) presents a scene of a marriage chariot and ceremony. Women were highly involved in the ceremony such as the woman pictured among the horses providing the festival music. The painted wife holds the reins and controls the chariot herself.

The ring (Figure 3) depicts a young woman visiting with Eros the god of love. She dresses as the upper class would. These types of rings were worn by men or placed decoratively in one's home instead of on a woman's finger.

The Funeral statues presented in Figure 4 depict a highclass woman and her handmaiden. These figures would have been present on an upper-class woman's grave to celebrate 


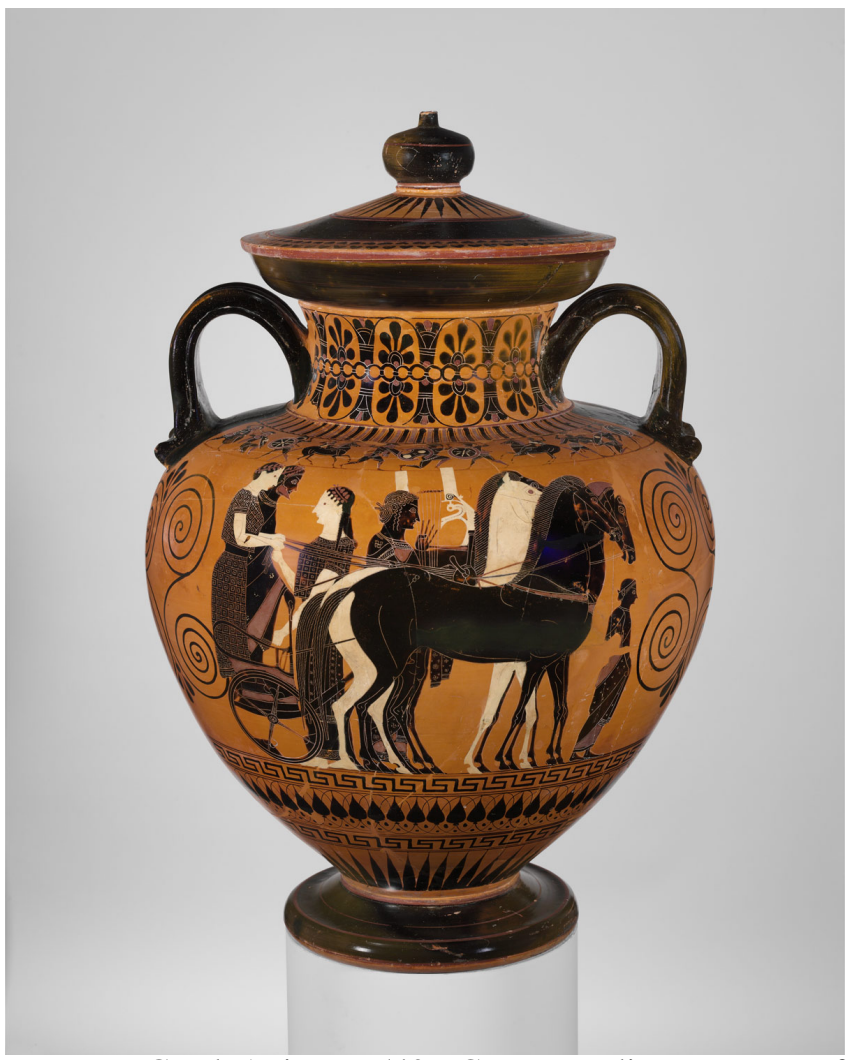

Figure 2. Greek Attic, ca. 540 BC, Metropolitan Museum of Art

her. She is wearing a dress reserved for young virgins who led processions to sacrifice. This position was highly respected.

The bowl depicted in Figure 5 represents a popular artistic style of the Classical Period - women in intimate settings with one another. The women depicted on the bowl pay rapt attention to the woman sitting playing the lyre. The women are deeply moved by the other woman's song and embrace one another in intimacy. It is theorized that the woman sitting could depict Sappho performing for her female students. ${ }^{12}$

\subsection{Female Deities and Religious Significance}

The beliefs the ancient Greeks held about mythical women do not correspond with the supposed treatment of women in their society. Goddesses in Greek mythology were held in the same high regard as their counterparts. Goddesses such as Aphrodite, Hera, Hestia, and Hekate were immensely powerful and worshipped by men and women alike. These goddesses had as many holidays and festivals in their honor as did the male gods. Artemis was feared because of her great ability with a bow while Athena was widely respected and often gave advice to famous Greek heroes. The Greek goddesses were deeply important to the Greek people. Both men and women were raised hearing the stories of Demeter's saving her daughter Persephone, or the wickedly intelligent Aphrodite's

\footnotetext{
${ }^{12}$ Colette Hemingway, "Women in Classical Greece," In Heilbrunn Timeline of Art History(2000).
}

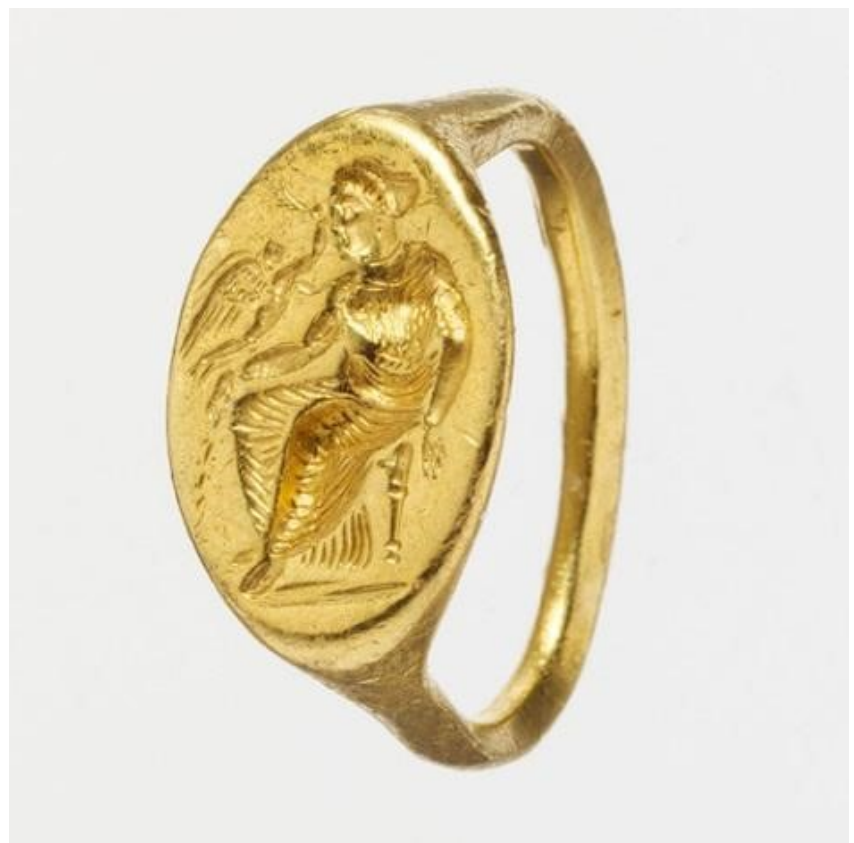

Figure 3. Greek, 2nd half of 5th Century BCE, The Metropolitan Museum of Art

involvement in the Trojan War. The argument that ancient Greek men would openly worship and revere goddesses that embody femininity, while simultaneously feeling no respect for their wives and daughters, is unsound. Athenian belief in goddesses and Amazons skilled in battle and great in intelligence was incompatible with their supposed treatment of women in the time period. However, the attitude and respect held for goddesses does not necessarily correlate to mortal Greek women. Goddesses and mortals would have been understood in vastly different spheres of ability and influence, yet the lines between goddess and mortal do occasionally blur within Greek dramas in depictions of feminine heroines such as Lysistrata and Penelope.

\subsection{Athenian Women}

The presumed cruel treatment inflicted upon Athenian women by their male counterparts clashes with the classical Greek obsession with the mythical Amazonian women. Homer was the first to begin the widespread interest in Amazonians. ${ }^{13} \mathrm{He}$ named them the "Amazons antianeirai" which can be translated "the equal of men." Homer's characters boasted of killing these women because the women were such dedicated and skilled warriors. ${ }^{14}$ They were said to be so resolute in battle that all the women cut off their left breasts to remove the obstacle when carrying or shooting a bow. Towering, scantily clad women warriors began to be depicted on much of Greek artwork in the sixth century B.C. and beyond. The Amazonian women became so romanticized by Athenian men that the myth became a trope in Greek culture alike to the

\footnotetext{
${ }^{13}$ Amanda Foreman, "The Amazon Women: Is There Any Truth Behind the Myth?" Smithsonian Magazine, Apr. 2014, 1.

${ }^{14}$ Iliad 3.185.
} 


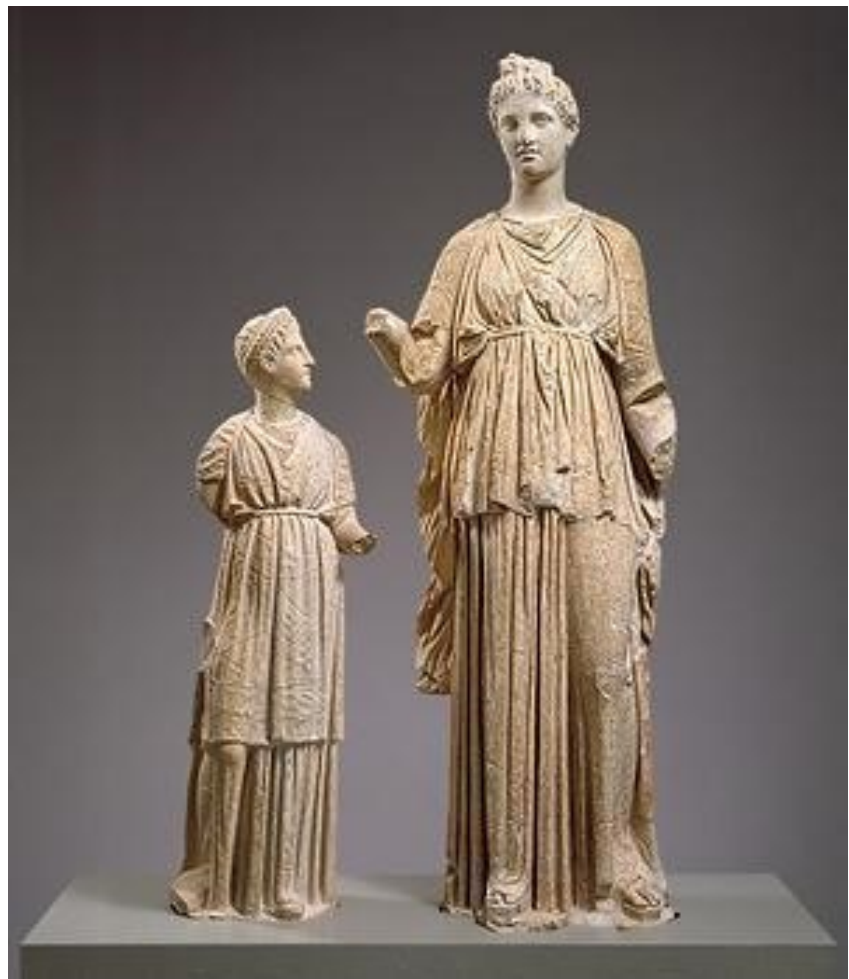

Figure 4. Greek Attic, Late Classical ca. 320 BC, Metropolitan Museum of Art

American obsession with vampires or zombies. Everywhere Athenians went they were surrounded by Amazonian artwork and literature. Further into the sixth and fifth centuries the myth surrounding the Amazonians grew. Greeks believed that the great women procreated once a year with a neighboring tribe and sent the male babies away but kept the females to train in battle. The ancient Greek historian Herodotus wrote that the Amazonian "marriage law lays it down, that no girl shall wed until she has killed a man in battle." 15 The romanticized obsession with powerful Amazonian women raises questions about the Athenian man's psyche. If the men of the time found powerful and skilled women beautiful and interesting why would they keep their wives trapped in their homes as Gomme has said? Athenian men may have commonly believed following Aristotle, that "the male... [was] by nature more expert at leading than the female" and that "the relation of male to female is by nature a relation of superior to inferior and ruler to ruled." 16 And yet the same men were fascinated by women who were intelligent enough to govern and run an entire society composed solely of women. The religion and myths of the Greek people are not consistent with the speculated callous attitude men held towards classical Greek women.

\footnotetext{
${ }^{15}$ Herodotus 4.117

${ }^{16}$ Politics $1.1254 \mathrm{~b}$.
}

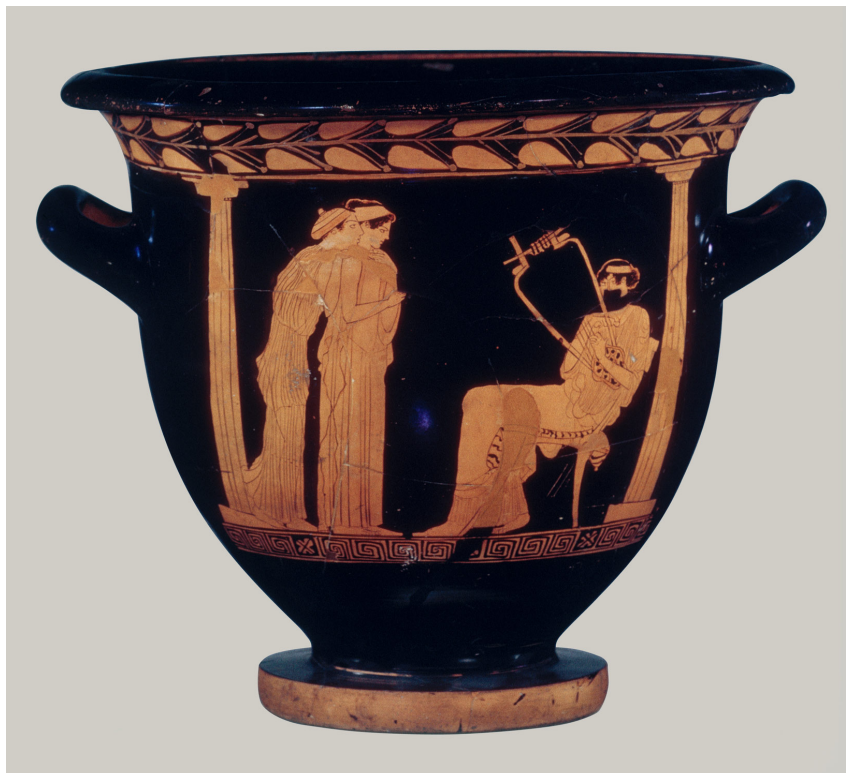

Figure 5. Greek Attic, ca. 460 BC, Metropolitan Museum of Art

\section{Ancient Literature about Greek Women}

Books 7 and 8 of Herodotus are important to understanding the Greek male psyche on the subject of feminine power and respect. These books feature the queen of Halicarnassus, Artemisia. Herodotus' respect for Artemisia borders on the obsession Greek men had with the mythical Amazonian women. Artemisia was one of Xerxes' commanders and advisors in Persia's battles although she was a Greek herself. Herodotus writes that Xerxes respected Artemisia immensely and listened to her advice in battle more so than he did to of any of his male commanders. Herodotus presents Artemisia as intelligent through his tales of how she manages to save herself and destroy her enemies. Artemisia does well in battle, leads her own naval fleet, and becomes Xerxes' only trusted advisor. When Artemisia proves herself over her male counterparts, Xerxes says, "my men have become women and my women, men." ${ }^{17}$ Although this quote is sexist it still dictates that some women are deserving of respect. Herodotus' tale is one of a woman proving she is more capable than a man. Although it is not Artemisia's feminine traits that are respected in the story it is still important that strong women were taken seriously by the Greeks.

\subsection{Lysistrata}

Greek women in plays and literature often directly clash with the misogynist assumption applied to the Classical time period. Athenian women were written as complex, intellectual, and sometimes very powerful characters in plays, such as $L y$ sistrata, and in other works of literature. The play Lysistrata acquires its name from the main character of the story. Lysis-

\footnotetext{
${ }^{17}$ Herodotus 7.88.
} 
trata has an idea that will be "the salvation of all Greece."18 She plans to unite all the women in Greece so they can deny their husbands sex as long as the bloody and pointless Peloponnesian War rages on. The women of the play are cast in much fairer lights than their male counterparts. The men-mostly the Chorus of Old Men and the Commissioner-are mocked and laughed at by the women of the play. The women are successful in their attempts to stop the war and the tale ends with the women celebrating their ideas over the stupidity of men. Lysistrata's character is the most logical and intelligent person portrayed in the comedy. In one particular scene the mortal Lysistrata is strongly paralleled with the goddess Athena in her struggle for peace. In the last scene of the play "the portals" of the stage open and "Lysistrata appears wearing the aegis of Athena and flanked by all the Athenian and Spartan women." ${ }^{19}$ Lysistrata's takeover of the Acropolis-a representation of Athenian politics-evokes not only Athena but also the powerful Amazonians. ${ }^{20}$ The ending lines of Lysistrata are "Athena the fair." 21 Although Lysistrata is a mortal woman in the play who is often sexualized along with the other women she still ends the play representing one of the most powerful goddesses. Even before her act of dressing as Athena, Lysistrata still represented the goddess because her "name is a thinly veiled reference to Lysimache, who was the priestess of Athena Polias." 22 If Aristophanes wrote his mortal feminine character as a representation of a goddess, the idea of Greek women-especially heroines-resembling goddesses may not have been so foreign to classical men.

Lysistrata herself not only represents Athena but also the actual powers of Athenian women in Aristophanes' time. Lysistrata can be read as a metaphor for the contradictory status of Athenian femininity and its relationship with Athenian rituals and ceremonies. She tells the magistrate that the Greek "citizen body is a raw fleece," and to repair Athens they must "beat out villains with a stick" just as the women "pick out the burrs" from wool. ${ }^{23}$ Athenians must "knot themselves together" alike to weaving. ${ }^{24}$ Lysistrata's weaving metaphor represents the classically accepted ideal of ancient femininity within the household. However, Lysistrata extends the metaphor into Athenian political life. This act manages to masculinize this feminine activity by pushing it out of the domestic sphere. Her femininity is further pushed from its domestic sphere when she takes on the form of the feminine goddess Athena on the Acropolis. The Acropolis is the center of political and social life in Athens and has been taken over by women just as the war will end because of women. The final setting of the play is important in demonstrating

\footnotetext{
${ }^{18}$ Aristophanes, Translated by Alan H. Sommerstein. Lysistrata and Other Plays, (London: Penguin, 2002), 30.

${ }^{19}$ Aristophanes, Lysistrata, 1271.

${ }^{20}$ Kate Gilhuly, The Feminine Matrix of Sex and Gender in Classical Athens, (Cambridge: Cambridge UP, 2009), 146.

${ }^{21}$ Aristophanes, Lysistrata, 1321.

${ }^{22}$ Gilhuly, The Feminine Matrix of Sex and Gender in Classical Athens, 148.

${ }^{23}$ Aristophanes, Lysistrata, 575.

${ }^{24}$ Aristophanes, Lysistrata, 578.
}

how femininity is able to overtake masculine settings and can accomplish massive political tasks such as ending a war. "Lysistrata's weaving metaphor, her explicit association with her father, her masculinity, and the setting of the play on the Akropolis" not only exhibits the varying degrees of femininity of Athenian women but also their roles in rituals. ${ }^{25}$ Women's importance in religious rituals is discussed multiple times throughout Lysistrata and help to demonstrate how key Greek women were socially. The old women in the play claim they have the authority to advise the city politically because they have participated in civil rituals throughout their lives and are therefore important citizens in their community.

I shall give good advice to the City: For my nurture, I owe her no less. I became, at the age of seven, an Acropolis child priestess; Then, after I'd serve as a Grinder, to aged ten, I went down as a Bear in the rites of the Foundress, and discarded my saffron-dyed gown; and finally I was selected the ritual basket to bear. $^{26}$

The older woman of the chorus uses various examples of how women were involved in rituals that were necessary in their religion and to their society. Women associated with priesthoods and religious rituals are usually depicted as chaste and therefore in a different sphere than most Athenian women who would have been married and placed in a different position of power than these religious figures. However, women who were priestesses for certain goddesses and worked within their temples did not always serve every day of their lives. For example, the priestess positions of the Athena Nikê temple were awarded by lot and did not serve daily. Therefore, the women who worked within this temple would have important ritual duties yet also remain married. As Gilhuly notes,

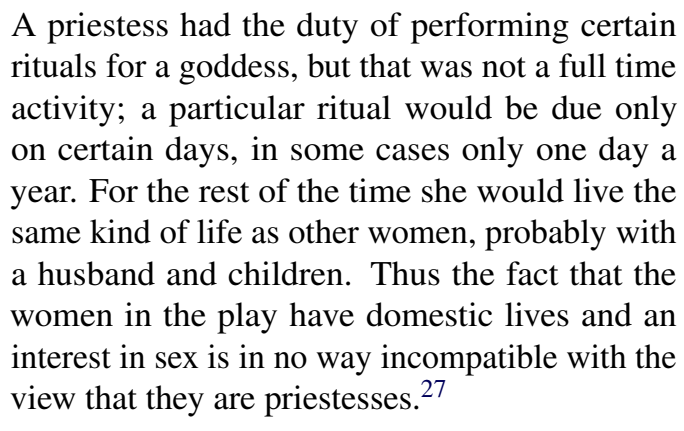

The ability of wives and mothers to be priestesses removes the idea that women of religious stature were more powerful because they were devoid of sexuality. The women of Lysistrata are overtly sexual throughout the play and are also powerful enough to overtake the Acropolis. While it is the older de-sexualized women who force the men out of the

\footnotetext{
${ }^{25}$ Gilhuly, The Feminine Matrix of Sex and Gender in Classical Athens, 147.

${ }^{26}$ Aristophanes, Lysistrata, 638-646.

${ }^{27}$ Gilhuly, The Feminine Matrix of Sex and Gender in Classical Athens,
} 
public space, it is still the young Lysistrata who appears in Athena's aegis in the center of the Acropolis. Sexuality and power can and do intertwine in Athenian women. The entire play-from its characters to themes to plot_acts to oppose the idea that women are not as intelligent or as celebrated as men in ancient Greece. Prominent is the dissonance between the accepted views of the mistreatment of women in classical Athens and rather different impressions conveyed by the religion, myths, art, and literature of the time.

\section{Women in Greek Philosophy and Literature}

Greek philosopher Diogenes Laertius' biography "The Life of Hipparchia" takes place circa 300 BC. The narrative follows Hipparchia; a woman going toe to toe with her husband by repeatedly outsmarting him. In the account Hipparchia's husband questions why his wife does not act as the stereotypical woman might. Hipparchia responds that "instead of wasting [her] time at the loom [she has] used it for [her] education" Laertius then comments that this saying is "among the numerous sayings of the woman philosopher." 28 The appearance of a cliché about women philosophers means there were numerous female philosophers. A cliché would not materialize if just a few women were philosophizing. Hipparchia was a known Cynic philosopher in classical Greece who studied under the Theban Cynic philosopher Crates. ${ }^{29}$ The philosopher Plato also took in female students into his Athenian Academy. ${ }^{30}$ In his Republic Plato argued that upper-class women should be reared and trained alongside Greek men because they are as rational and spiritual as men. ${ }^{31}$ Plato also argues that men and women should not be treated differently because male and female animals are treated the same. He even proposes that women should be allowed in the gymnasium along with men and to play sports at all ages. ${ }^{32}$ Greek female philosophers were emerging within Athens and were being taught by famous male philosophers alongside Athenian men.

The religion of the Greeks is important to understanding how they valued and felt about femininity and women. The Homeric Hymn to Demeter is an excellent example of a Classical tale defining the roles and characteristics of the goddesses and gods the Greek worshipped. The hymn is centered on the Greek goddess Demeter's attempts to free Persephone from Hades. Instead of delegating the task to one of the masculine gods, Demeter speeds "off like a bird, soaring over land and sea, looking and looking" for Persephone. ${ }^{33}$ During her search she goes to the Sun God for guidance. The Sun God replies that he will help her because he "greatly respects" Demeter. The relationship between the Greeks and their religion is im-

\footnotetext{
${ }^{28}$ Laertius, 6.98 .

${ }^{29}$ Laertius, 7.96 .

${ }^{30}$ Sarah B Pomeroy, Ancient Greece: A Political, Social, and Cultural History, (New York: Oxford University Press, 1999), 398.

${ }^{31}$ Republic, 5.450 .

${ }^{32}$ Ibid. 5.451

${ }^{33}$ Homeric Hymn to Demeter.
}

portant to understanding how their society would react to this story. Demeter is the sympathetic hero of the hymn and the reader or audience is naturally supposed to feel her pain and hope for her success in rescuing Persephone. If the audience is supposed to care for Demeter and worship her, they cannot hate her feminine qualities. Demeter acts as a mother searching for her child- a conventionally feminine goal—and the Sun God respects Demeter and her quest enough to disobey Zeus and Hades to help the woman of the tale. Zeus and Hades - total representations of masculinity — are seen as the antagonists of the hymn. Amazonian and goddess femininity were not understood to represent mortal femininity to the Greeks. However mortal women within literature were also written and read as heroic within their own spheres.

Although she is a character of legend, Homer's Penelope is still a mortal female character who exemplifies heroic traits and embodied feminine morality and intelligence for classical Greeks spanning generations. Penelope demonstrates her intelligence in her weaving scheme, her recognition of her husband, and her creation of the bow competition following the recognition. Penelope tricks the suitors by promising she will pick a new spouse once she has finished weaving a burial shroud for her father-in-law. Once she has finished the shroud she will remarry and her new husband will be allowed to Odysseus' land and wealth. However at night Penelope unravels all the weaving she has done on the shroud during the day to prolong the process and hold off remarrying. ${ }^{34}$ Penelope's method of resisting the suitors is interesting because she succeeds in outsmarting them through an act which represents domesticity and femininity. The suitors are powerless to force Penelope to marry any of them as long as she is using her feminine weaving trick against them. This weaving metaphor and its representation of domesticity and the power within the feminine were also demonstrated within Lysistrata, as discussed previously. Penelope further proves her intelligence in her early recognition of Odysseus even though she does not directly state she has discovered the beggar's identity. Following Odysseus' conversation with Penelope while he is dressed as a beggar in Book XIX, Penelope claims she will marry the man who can string and shoot Odysseus' bow through a line of twelve axes. ${ }^{35}$ It seems much more likely that Penelope recognizes Odysseus in his disguise and thought of a plan to give Odysseus a weapon than just randomly create a competition for the suitors. It would also be very coincidental that the day Odysseus returns home would be the day Penelope decides to remarry. It is only by using his bow-provided to him by Penelope for the competition-that Odysseus is able to slay the suitors in Book XXII, retake his home, and reunite with his family. Penelope's heroism and intelligence within the household are vital in helping Odysseus return home, and Homer has created a well-rounded and wholly feminine character who remains respected and moral throughout the text.

Penelope represents feminine bravery within the house-

\footnotetext{
${ }^{34}$ Odyssey Book II

${ }^{35}$ Ibid. Book XXI
} 
hold while many of Euripides' female characters personify feminine bravery in the state. All that remains of Euripides' drama Erechtheus is Praxithea's speech about how women are equally worthy as men to be sacrificed for their homes and people. One of Praxithea's daughters must be sacrificed for the family's city. When asked about the sacrifice, Praxithea states:

If there were in our household male offspring instead of female, and the fire of war occupied the city, would I not be sending my son into battle with the spear...May I have children who fight and are preeminent among men, and not be mere figureheads in the city...when children die in war they share a common tomb with many others and an equal fame. But my child shall have a crown that is unique as her reward for dying alone on behalf of this city. ${ }^{36}$

Praxithea's speech deals directly with feminine heroism and the ability for women to be equal to men in sacrifice if not surpass it. Euripides' Erechtheus is mostly lost but this one passage is filled with what must be Classical feminism. Praxithea acts as a wise and heroic motherhood figure while the sacrificed daughter embodies the strength of feminine qualities. Praxithea's daughter does not need to participate in the masculine sport of war to be important to the Greek society. She is uniquely brave in a way the soldiers of Greece cannot be. Praxithea's daughter will fight through her sacrifice instead of merely existing in the city like a "figurehead" as Praxithea fears. Euripides has provided evidence that feminine bravery to the Greeks was possible and could not be achieved by merely being seen as objects. Praxithea's speech about sacrifice was so important to the Greeks that it was performed by Lycurgus as the epitome of "women's heroism" in fourthcentury Athens.

One speech of Medea's, after she has been abandoned by her husband Jason, especially demonstrates the struggles of Greek women and dramatizes how gender relations need to change within the Greek world. Medea states that the "sudden blow" of divorce has "destroyed [her] life" because "the man in whom all [she] had was bound up" has abandoned her. ${ }^{37}$ Medea's speech demonstrates the fundamental flaw of divorce within Greek society because women who are divorced no longer have a way to provide for themselves, and all their monetary abilities have faded with their husband's abandonment. Euripides has written Medea's speech to question this unjust system within Greece. He continues his contesting of gender inequality by questioning the morality of the dowry system. Medea proclaims that "women are the most unfortunate" of all creatures because they are the only ones that "must buy a husband and master of [their] bodies" because "it is not possible to refuse wedlock." 38 Medea's critiques of the dowry

\footnotetext{
${ }^{36}$ Euripides, Erechtheus, Translated by Mary R. Lefkowitz, 6 .

${ }^{37}$ Euripides, Medea, 225.

${ }^{38}$ Ibid. 230-235.
}

and marriage system forced upon Greek women indicate that Greek men-such as Euripides and perhaps the men watching the drama performed - understood that the genders were unjustly unequal. Understanding the social, political, and economic inequalities of women does not, however, translate to attempting to fix the issues. Still, the creation of the character Medea and her speeches written for the public format reveals a desire of Euripides to unveil the issues of gender inequality within Greece.

Medea's speech also displays heroic feminism similar to Euripides' Praxithea in her speech about the sacrifice of women compared to that of men. Medea states-in in response to Greek men who believe women "live a life free from danger" - that she "would rather stand three times with a shield in battle than give birth once." ${ }^{39}$ Euripides seems to understand the extreme danger women had to face when giving birth and also their extreme bravery because of this risk. In Medea's speech, Euripides is demonstrating how Greek women led dangerous lives just as their male counterparts did. He understands feminine bravery and their exceptional courage and worth to both their husbands and the Greek state by putting their lives at risk by having children. Euripides in both Medea and Praxithea has examined feminine heroism and deemed it as valuable as male heroism if not more so. Medea is not a traditional representation of heroic femininity because of her actions later in the drama, but Euripides has still created a feminine character with both flaws and strengths. She does not act as a simple backdrop to her husband's narrative. Instead the drama is titled Medea and her speeches demonstrate the value, intelligence, bravery, and frustrations within Greek women because of unjust gender roles.

\section{Legal Rights of Greek Women}

While there is not a plethora of information on the legal abilities of Athenian women, there are still some primary-source documents that demonstrate the rights of women in the court system of Athens. The legal abilities of women in Greek cities such as Athens are difficult to determine because of varying cases and a lack of documentation. "Under Athenian law" women were able to "inherit, but they [did] so as sisters (or cousins)" because they had to retain agnatic ${ }^{40}$ ties to their natal families. ${ }^{41}$ Women's inheritance claims were not only recognized in Athenian courts but the women were listed as active disputants and were legally able to bring cases to court themselves. The legal documents listing Athenian women as active disputants conflict with the conclusions of Balme and Lawall, whose textbook asserts that women were treated the same as children in Greek courts. Athenian women's in-

\footnotetext{
${ }^{39}$ Euripides, 250

${ }^{40}$ Agnatic legacy is based on inheritance through ties to a father. For example, a Greek woman would inherit property from her father before her brother's sons did so. She would attain equal property from her father as her brother did.

${ }^{41}$ Virginia Hunter, Policing Athens: Social Control in the Attic Lawsuits, 420-320 B.C., (Princeton, NJ: Princeton University Press, 1994), 14.
} 
heritance rights were strong enough to descend through their children as well. Poor Athenian women were often documented as legally becoming head of household after the death of their husbands. ${ }^{42}$ However these documented accounts of women who were members of the working poor may prove how gender roles were less enforced in lower classes only by necessity.

\section{Ancient Literature written by Greek Women}

Primary sources written by women of the time period are few and hard to come by. Most have been destroyed or are rumored not to have been written by women at all. The philosopher Phintys wrote a piece "on the temperance of a woman" in the second century B.C. ${ }^{43}$ Phintys believed that a woman would be most able to honor and love herself and her husband through temperance. Phintys stated that "the principle virtue of a woman is temperance." 44 She thought that certain factors of life such as leading an army or governing belonged more to men than women. However, she also felt that women had just as much right to "philosophize. . . ride on horseback. . . [and] harangue in public" as men did. Husband and wife should have alike virtues of the body and soul. Men and women were alike in that a healthy body made for a healthy soul. Phintys states that lower class women often-and must-leave their homes to help provide for their city, husbands, and all their family. A high-class woman should often depart from her home as well to purchase something she desires or needs. The woman of the home did all the shopping for the family and her husband while he worked during the day. Phintys' direct account of women in their day-to-day lives in ancient Athens does not match Gomme's account. While he says that women were trapped in their bedrooms for most of their lives, Phintys - a woman of the time - states that women often left the home and spent time in the large market place in town. Many historians state that women could not be seen by men who were not their husbands. However Phintys' account contradicts this idea. A woman of high stature would be seen by a vast number of men if she left the home every day to travel to the "forum" when it "[was] full of people." 45 Both lower and upper class women were thus able to participate in town markets and were occasionally able to gain paid employment. $^{46}$

Continuing on the subject of primary sources, the oldest epigram found from the Classical time period was written by Erinna, featured in Meleager of Gadara's introduction to Garland. Erinna's epigram was most likely written in $353 \mathrm{BCE}$, making it the earliest Greek epigram found. ${ }^{47}$ In the epigram

\footnotetext{
${ }^{42}$ Ibid, 29.

${ }^{43}$ Phintys, 1937.

${ }^{44}$ Ibid.

${ }^{45}$ Ibid.

${ }^{46}$ Hunter, Policing Athens, 34.

${ }^{47}$ Marilyn B. Skinner, "Making Silence Speak: Women's Voices in Greek Literature and Society," Choice Reviews Online 39.10 (2002).
}

Erinna praises a portrait of a woman named Agatharkhis. The first Greek epigram about a piece of art being written by a woman is substantial in determining the importance of women to Greek society. Meleager-a famous male poet of the Classical age - featured Erinna in his book and lists Erinna as "the sweet maiden-complexioned crocus of Erinna" among many other poets_-male and female alike-in Garland. Erinna's epigram and its presence in a famous male poet's book demonstrates how classical women did not always fit into the mold of child bearer without any literary training. For instance, Erinna is obviously educated because she has written an epigram and alludes to Prometheus in her epigram. Erinna has been trusted by the artist of Agatharkhis to write her opinion of the piece of art and her opinion is important enough that her epigram is implemented in a book of poetry because of the beautiful way she composes her thoughts. Women's opinions about art and literature must have been important if Erinna was respected in these ways.

One quote from Erinna's epigram about the work of art titled Agatharkhis can be looked into further to discuss the importance of a Classical woman's voice and thoughts. Erinna dictates that "if whoever painted this maiden so truly had just added a voice, you would have been Agatharkhis entirely." 48 This quote is praising the artist but Erinna is also commentating that women are incomplete without their voices. Agatharkhis may be presented as beautiful in the painting but she is not complete because she lacks a voice. The woman in the painting lacks thoughts and opinions so she is not here in her entirety. Instead of being sexualized or thought of as an object for men to look upon, the painting Agatharkhis is judged by a woman and is only flawed by the lack of thought the woman is able to have.

The relationships and sexuality between women is important to discovering the differences between the spheres of men and women. A few primary sources give an insight into the relationships between women absent men. Nossis' epigram about Sappho exhibits the admiration women had for other women and the sphere of literary women interacting with one another. Sappho is one of the most important poets from the Classical era and Nossis tries to imitate Sappho's lyrics in her own poetry. Nossis was a Hellenistic woman living in the third century BCE in southern Italy. ${ }^{49}$ Nossis is important because her work shows that women's poetry-Sappho's in particular-was important enough to spread throughout most of the Hellenistic world. Nossis compares Sappho to Aphrodite and her poems to roses. Nossis' epigram is wholly feminine. It is a poem written by a woman, about a woman who is then compared to a feminine deity. To Nossis "nothing is sweeter" than Sappho's poems. ${ }^{50}$ All of Nossis' "other delights are second" to her admired Sappho. There is no mention of men or masculinity in this poem, only feminine language and admiration from one female to another. Nossis' admiration of

\footnotetext{
${ }^{48}$ Erinna G-P 3.

${ }^{49}$ Skinner, "Making Silence Speak."

${ }^{50}$ Nossis G-P 1.
} 
Sappho does not fit into a society where women are utterly repressed and kept in their homes without any sort of education. Sappho was popular enough that many women-and men too-throughout Greece were reading her poetry. Nossis' response to Sappho and her poetry reveals a whole sphere of women writers and fans that are never mentioned in classical historians' reports.

Another important epigram written by Nossis is addressed to "elthoisai," apparently a group or "circle of women." The word "elthoisai" is grammatically feminine and placed at the beginning of the epigram to emphasize that women alone are traveling to Aphrodite's temple. ${ }^{51}$ Aphrodite's statue before the temple is constructed wholly of gold and is apparently modeled after the beautiful Polyarchis; a Greek courtesan. Nossis writes that the statue was modeled after Polyarchis because "of the splendor of her own body." Nossis is once again acting as a woman supporting a woman. Like Sappho before, Nossis greatly admires a woman and her accomplishments, be they literary or bodily. The feminine sexuality is often discussed in Nossis' writing. In Nossis' epigram about Sappho the word "desire" is sexually charged while in this epigram Nossis' discussion of the beauty of Polyarchis' body is sexual as well. Nossis once more presents us with another poem wholly absent of men. This epigram tells a story of a group of women worshipping at women's temples. The Greek words used in the epigram by Nossis are thoroughly feminine as well. These women apparently had their own spheres, where they read one another's poetry and traveled in groups to worship Goddesses. Athenian men may have had a monopoly on public authority and public space but ancient women had "developed an institutional structure and sense of solidarity of their own, parallel to those of men." 52

\section{Conclusion: Historical Discord}

One possibility for the dissonance between primary sources and historical works is the misogynistic tendencies of the men who dictate history. A. W. Gomme is an excellent example of an author who has put his own male spin on historical evidence. Texts that were written in times when sexism was prevalent, such as the early 1900s, are going to reflect that bias. ${ }^{53}$ Gomme's ideas of Greek women are further contrasted by that of the more modern David Cohen. Cohen argues that Athenian women were treated in the same fashion as women in Great Britain in the 1980s. Greek women may have led separate lives from most men but that does not make them secluded or isolated. Women had intimate friendships with one another, while women of lower classes supported themselves by selling food and trinkets in the marketplace. ${ }^{54}$ The clashing evidence on Greek women is important to note

\footnotetext{
${ }^{51}$ Skinner, "Making Silence Speak."

${ }^{52}$ Hunter, Policing Athens, 34.

${ }^{53}$ Marilyn Katz, "Ideology And 'The Status Of Women' In Ancient Greece." History \& Theory. 31.4 (1992) 70.

${ }^{54}$ David Cohen, "Seclusion, Separation, and the Status of Women in Classical Athens." Greece \& Rome (1989), 255.
}

because the amount of directly paradoxical information given by experts does not allow for any true understanding of ancient Greek women.

These findings in the research of Greek women are startling because the importance of historical bias becomes apparent. The accuracy of men like A.W. Gomme is not usually questioned because of the assumption that his findings must be correct. Textbook writers such as Balme and Lawall replicate Gomme's views within their textbooks, leading to the flawed scholarship that influences student understanding of the roles and abilities of ancient women. Very few primary sources from the time period written by women exist; we thus rely on research of previous historians. When these historians, who are supposed to present research in an unbiased and complete way, fail to do so, all present-day scholars suffer. The main problem with simply believing what previous historians have dictated is that the truth can become convoluted. On the topic of Greek women in particular, historical accuracy is important because ancient history sets the stage for how groups of people will be treated in the future.

\section{Author Biography}

Caitlyn Coil is a native of Denton, Texas. She received her Bachelor of Arts in History in May, 2017. Caitlyn is currently a law student at SMU's Deadman School of Law. 